\title{
大型せん断土槽を用いた液状化害験における 基礎根入れ部に加わる土圧合力の評価 \\ EVALUATION OF SEISMIC EARTH PRESSURE ACTING ON EMBEDDED FOOTING BASED ON LIQUEFACTION TEST USING LARGE SCALE SHEAR BOX
}

\author{
時松孝次*1, 田村修次*2, 宮崎政 信*3, 吉 澤睦 博*4 \\ Kohii TOKIMATSU, Shuji TAMURA, Masanobu MIYAZAKI \\ and Mutsuhiro YOSHIZAWA
}

\begin{abstract}
Large-scale shaking table tests are conducted to evaluate seismic earth pressures acting on an embedding footing during soil liquefaction. The threshold soil displacement relative to the footing, above which the earth pressure begins to increase, increases with the development of loosened zones around the footing. A new seismic earth pressure theory considering the loosened zones is developed, by extending the one proposed by Zhang et al. (1998). The earth pressures evaluated by the proposed method show good agreement with those observed in the tests.
\end{abstract}

Keywords: Soil liquefaction, Earth pressure, Pile foundation, Dynamic interaction 液状化、土圧、杭基礎、動的相互作用

1. はじめに

1995年兵庫県南部地震では、液状化に伴う地盤変形によって、多く の杭基礎構造物が被害を受けた 1).2)。これをふまえ、液状化地盤にお ける杭基礎举動に関する多くの研究畞え(13)-6) が行われている。その結 果、液状化層の上に存在する非液状化層が、杭基礎に被害を与えた可 能性が指摘(5), ‘)れている。これは、一般に基礎根入れ部の土圧は、 上部構造物の慣性力に対して抵抗側に働くため、杭頭水平力は慣性 力より小さくなると考えられている71,8)が、液状化による地盤変形が 加わると、土圧が加力側に働き、杭頭水平力を增加させる場合がある ためと考えられる。

地震時土圧理論としては、従来から、物部 ${ }^{99}$. 岡部10) が最も一般 的に用いられてきている。物部・岡部式は、主働および受働の極限 状態における土圧算定法であり、その中間状態の土圧が評価できな

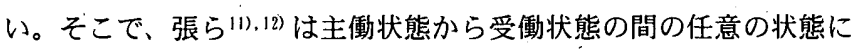
おける地震時土圧理論を提案している。しかし、これらの土圧理論 が、構造物と地盤の相対変位が極めて大きく、かつ繰り返し回数も 多い、液状化地盤の土圧推定に対しても有効であるかどうか不明で ある。一方、理論の妥当性を検討するため、模型基礎や実構造物に

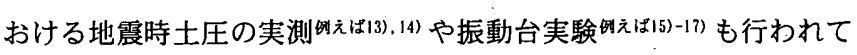

いるが、液状化層の上に存在する非液状化層に着目して土圧を検討 した例はない。

以上の背景から、筆者らは大型せん断土槽を用いた液状化振動台 実験において、表層の非液状化層が基礎根入れ部に及ぼす土圧合力 を検討し、土圧の発生メカニズム、相対変位と土圧合力の関係 ${ }^{18}$ およ び土圧合力と上屋慣性力の位相(19)について検討した。本研究では、大 型せん断土槽を用いた液状化実験に基づき、張らの提案する理論を 液状化層の上に存在する非液状化層の土圧に適用し、その有効性を 検討する。

\section{2. 実験概要}

実験モデルおよびセンサー配置を図一 1 に示す。せん断土槽は幅 $12 \mathrm{~m}$ 、奥行き $3.5 \mathrm{~m}$ 、高さ6mである。地盤は 3 層モデルとし、土槽底面

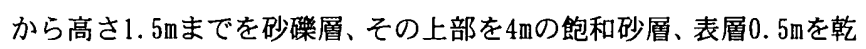
燥砂層とした。飽和砂層および乾燥砂層は、いずれも霞ヶ浦砂であ る。構造物モデルは、表－1に示すように、基礎部のみのB1モデル、 基礎部の上に周期 0.74 秒の上屋をもつBLモデ、周期0.19秒の上屋 をもつBSモデルとした。上屋の質量は $14.2 \mathrm{ton}$ 、基礎部は幅 $2.5 \mathrm{~m} 、$ 奥 行き $1.8 \mathrm{~m}$ 、高さ $0.6 \mathrm{~m}$ 、質量 $2.1 \mathrm{t}$ onである。杭基礎は、直径 $165.2 \mathrm{~mm}$ 、

\footnotetext{
*1 東京工業大学大学院理工学研究科建築学専攻 教授 · 工博

*2 信州大学工学部社会開発工学科 助教授・博士 (工学)

*3 侏) NTTファシリティーズ 修士(工学) (元東京工業大学 大学院生)

*4 㑣竹中工務店技術研究所 修士 (工学)
}

Prof., Tokyo.Institute of Technology, Dr. Eng. Assoc. Prof., Faculty of Engineering, Shinshu University, Dr. Eng. NTT Facilities Inc., M. Eng.

Research \& Development Institute, Takenaka Corporation, M. Eng 


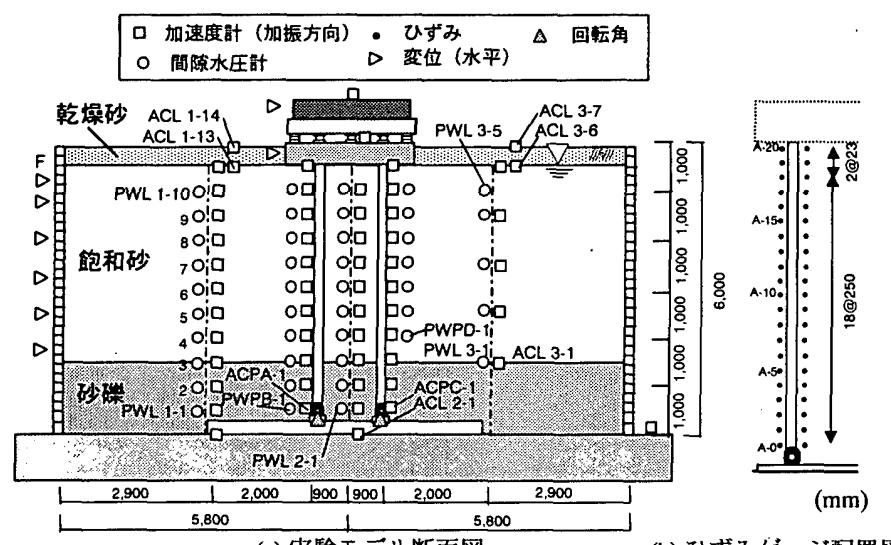

(a) 実験モデル断面図

(b) ひずみゲージ配置図

図ー1 実験モテルおよびセンサー配固 ${ }^{19)}$

表ー 1 構造物モテル

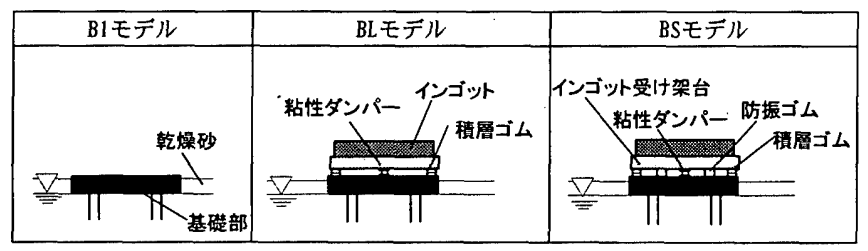

肉厚 $3.7 \mathrm{~mm}$ 、長さ $5.3 \mathrm{~m} 、 \mathrm{EI}=1259 \mathrm{kNm}^{2}$ の鋼管杭 4 本とした。基礎部と杭 頭は剛結合、杭端はピン結合とした。基礎部は乾燥砂層に $0.5 \mathrm{~m}$ 根入れ されている。自由地盤の卓越周期から換算される飽和砂層の $\mathrm{S}$ 波速 度は、B1で $93 \mathrm{~m} / \mathrm{s}$ 程度、BLで $91 \mathrm{~m} / \mathrm{s}$ 程度、BSで $84 \mathrm{~m} / \mathrm{s}$ 程度であった。一 方、砂砂層の $\mathrm{S}$ 波速度は $230 \mathrm{~m} / \mathrm{s}$ 程度である。入力波は人工地震波 「RINKAI92」20)を用いた。本研究では、入力波の最大加速度 $240 \mathrm{~cm} / \mathrm{s}^{2}$ の実験結果を検討対象とする。

\section{3. 張らの土圧理論に基づく土圧合力の推定值と実験値}

\subsection{B1モデルにおける地盤一構造物の応答および土压合力}

図一 2 に、B1 モテルにおける地表面加速度、入力加速度、間隙水圧、 基礎部と表層地盤の変位および相対変位、基礎根入れ部に加わる土 圧合力の時刻歷を示す。变位は加速度波形の 2 階積分から、土圧合力 $\mathrm{P}_{\mathrm{E}}$ は図ー 3 に基づいて次式で推定した ${ }^{18)}$ 。

$$
P_{E}=P_{E p}-P_{E a}=Q-F
$$

ここに、 $\mathrm{P}_{\mathrm{Ea}}$ は主働側の土圧、 $\mathrm{P}_{\mathrm{Ep}}$ は受働側の土圧、Qは杭頭せん断力、 Fは上屋之基礎部の慣性力の和 $\left(F_{1}+F_{2}\right)$ である。地表面加速度（図-2 a）は、サイクリックモビリティによると考えられるパルス状の波形 を示している。間隙水圧（図-2c）は、加振開始後 8 秒付近から上 昇し始め、約 10 秒で飽和砂層の上部、約 24 秒で飽和砂層の下部が液状 化したと考えられる。基礎部之表層地盤の変位振幅（図- $2 \mathrm{~d}$ ）は、 液状化が進行する 8 秒から20秒にかけて徐々に増加するが、その過 程で表首地盤の変位振幅が基礎部の変位振幅に比べて大きくなって いる。基礎部之表層地盤の相対変位振幅（図 $-2 \mathrm{e}$ ）は、8秒から 20 秒にかけて徐々に大きくなり、その後やや小さくなる。基礎部に加わ る土圧合力振幅（図一 $2 \mathrm{f}$ ） は 8 秒付近から急增し、12 20秒でほほ 一定になる。その後、土圧合力振幅は極めて小さくなる。このように 土圧合力振幅の時間変化は、相対変位のそれと異なる傾向を示す。
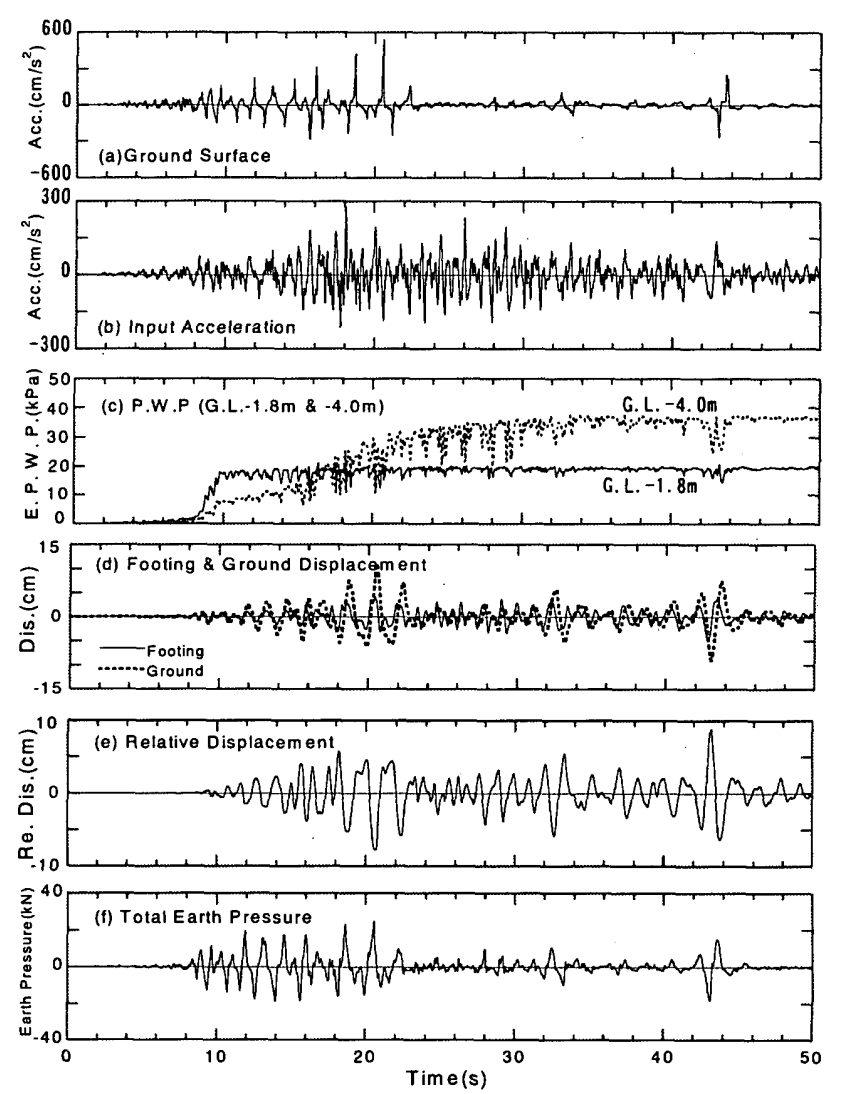

図 -2 加速度、間隙水圧、変位および土圧合力の時刻歴

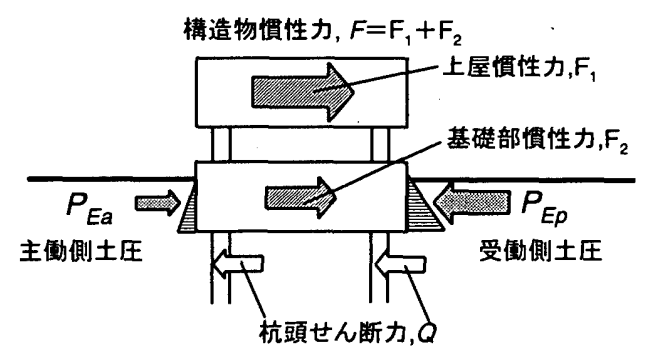

図一-3 基礎部に加わる力（模式図）

\section{2 張らの地震時土庄理論による土圧合力の評価}

地震が発生すると、地盤と基礎部に変位および加速度が生じ、図一 3 に示すように基礎部の左右で主働側および受働側の土圧が発生す る。底面摩擦、側面摩擦が主働側の土圧、受働側の土圧に比べて十分 小さいと仮定すると、張らの理論12)により、基礎部に加わる土圧合力 PEは次式で表される。

$$
\begin{aligned}
P_{E}=P_{E p}-P_{E a} & =B \int_{0}^{H} \gamma \cdot z \cdot \cos i\left(K_{E p}-K_{E a}\right) d z \\
& +B \int_{0}^{H} \gamma(H-z)(1-\cos i)\left(K_{E p}-K_{E a}\right) d z
\end{aligned}
$$

ここに、犺砂の単位体積重量、Hは根入れ部壁面高さ、iは地震合成 角、Bは壁面幅、また $\mathrm{K}_{\mathrm{Ea}}$ は主偅側の土圧係数、 $\mathrm{K}_{\mathrm{Ep}}$ は受働側の土圧係数 であり、次式で与えられる。 


$$
K_{E a}=\frac{2 \cos ^{2}(\phi-i)}{\cos ^{2}(\phi-i)(1+R)+\cos i \cos \left(\delta_{m o b}+i\right)(1-R) \cdot I_{E: 1}}
$$$$
(-1 \leq R \leq 1)
$$

$$
K_{E p}=1+\frac{1}{2}(R-1)\left(\frac{\cos ^{2}(\phi-i)}{\cos i \cos \left(\delta_{m o b}+i\right) \cdot I_{E .2}}-1\right)(1<R \leq 3)
$$

$$
\begin{aligned}
& \left(\begin{array}{l}
I_{E .1} \\
I_{E .2}
\end{array}\right)=\left[1 \pm \sqrt{\frac{\sin \left(\phi+\delta_{m o b}\right) \sin (\phi-i)}{\cos \left(\delta_{m o b}+i\right)}}\right]^{2} \\
& \tan i=k_{h} \\
& \delta_{m o b}=\frac{1}{2}(1-R) \cdot \delta_{a} \quad(-1 \leq R \leq 1) \\
& \delta_{m o b}=\frac{1}{2}(R-1) \cdot \delta_{p} \quad(1<R \leq 3)
\end{aligned}
$$

ここに、фは砂の内部摩擦角、 $\mathrm{k}_{\mathrm{h}}$ は水平震度、 $\delta_{\mathrm{mob}}$ はある相対変位にお ける剛性壁面の摩擦角、 $\delta_{\mathrm{a}} 、 \delta_{\mathrm{p}}$ は主働状態および受働状態における剛 性壁面の摩擦角である。Rは側方ひずみ拘束係数で、表一 2 に示すよ うに地盤と基礎部の相対変位から算定される。表中の $\Delta D$ D地盤と基 礎部の相対変位、 $\Delta_{\mathrm{a}} 、 \Delta_{\mathrm{p}}$ は主働および受㗢状態に達する相対変位であ り、次式で与えら抗る。

$$
\begin{aligned}
& \Delta D=\Delta B-\Delta S \\
& \Delta_{a}=\mathrm{a} \times H \\
& \Delta_{p}=\mathrm{b} \times H
\end{aligned}
$$

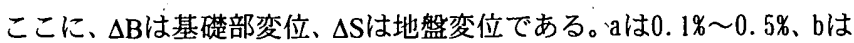
5〜10\%の值11)である。

（2）式において、地盤の単位体積重量、加速度および地盤と基礎部 の相対変位の深度分布が一定と仮定すると、(2)式は次式で表される。

$$
P_{E}=\frac{1}{2} \gamma H^{2} B\left(K_{E p}-K_{E a}\right)
$$

本研究では、地表面と基礎部根入れ深さ (GL. - -0. 5m)で実測された加速 度がほぼ同じであること、基礎部側面の摩擦を無視して土圧合力を 評価していることを考慮し、以下、（12）式に基づいて議論を進める。

$$
\text { 表 }-2 \text { 側方ひずみ拘束係数（張らの理論） }
$$

\begin{tabular}{|c|c|c|c|c|}
\hline & \multicolumn{2}{|c|}{ Active Side } & \multicolumn{2}{c|}{ Passive Side } \\
\hline$\Delta \mathrm{D}$ & \multicolumn{2}{|c|}{$\Delta_{\mathrm{a}}$} & 0 & \multicolumn{2}{c|}{$\Delta_{\mathrm{p}}$} \\
\hline $\mathrm{R}$ & -1 & $-\left(\Delta \mathrm{D} / \Delta_{\mathrm{a}}\right)^{0.5}$ & $3\left(\Delta \mathrm{D} / \Delta_{\mathrm{p}}\right)^{0.5}$ & 3 \\
\hline
\end{tabular}

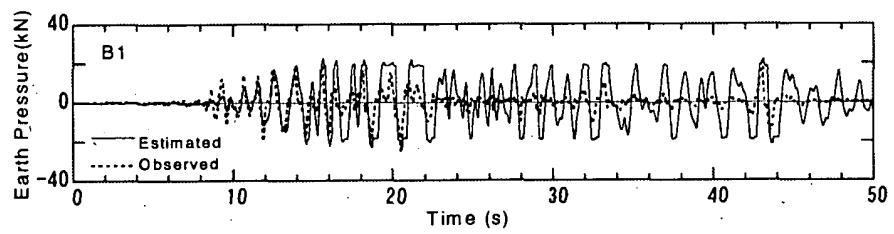

図ー4 土圧合力の実験值と張らの理論による推定值
張らの地震時土圧理論の妥当性を検討するため、砂の単位体積重 量を $17.64 \mathrm{kN} / \mathrm{m}^{3}\left(1.8 \mathrm{t} \mathrm{f} / \mathrm{m}^{3}\right)$ 、砂の内部摩擦角 $\phi$ を $30^{\circ}$ 、主働および受 働状態の壁摩擦角を $1 / 2 \phi$ と仮定し、(3)〜（12）式から土圧合力を推定 した。基礎部変位、地盤变位および地盤加速度は実験值を用い、(10) 式のaは0.5\%、(11) 式のbは5\%とした。図ー4に推定された土圧合力の 時刻歷を、実測された土圧合力と比較して示す。相対変位が增加して 土圧合力が最大になる12〜16秒にかけて、土圧合力の推定值は、実験 值と良く対応する。しかし、地盤が液状化した16秒以降、推定值は大 きな振幅を保ったままで、実験值の振幅が小さくなる傾向之対応し ない。したがって、張らの理論では、液状化進行に伴う土圧合力の増 加は説明できるが、液状化後の土圧合力の減少は説明できない。

\section{4. 受㒅状態に達する相対变位と土圧が増加しはじめる相対变位 \\ 4.1 受働状態に達する相対变位}

張らの理論で士圧の実験值を説明できなかった要因を検討するた め、図ー5 (a)に相対変位と土圧合力ピーグの関係を示す。なお、対 象とするピークは、土圧合力が $1 \mathrm{kN}$ 以上のものとした。図より、同じ 相対変位でも土圧合力は大きく異なることが分かる。例えば、相対変 位 $2 \mathrm{~cm}$ における土圧合力は $1 \mathrm{kN}$ から $20 \mathrm{kN} に$ 分布する。図中には受働状 態に達すると考えられる一般的な水平変位(壁面高さの5、10\%)"1を破 線で示している。相対変位が5cm（壁面高さの10\%）に達しても、土圧 合力が極めて小さいケースも存在する。これは、(11) 式で液状化地盤 が受働状態に達する相対変位を評価できないことを示唆している。

受動状態に達する相対変位をさらに検討するために、図一 5 (b)に、 土圧合力のピークのうち、相対変位が過去に生じた相対変位の最大 值を上まわるものを「・」で示す。相対変位が過去に生じた相対変位 の最大值を上まわるケースでは、相対変位が大きくなると土圧合力 も大きくなる傾向がみられる。また、図中に、張らの理論に基づいて
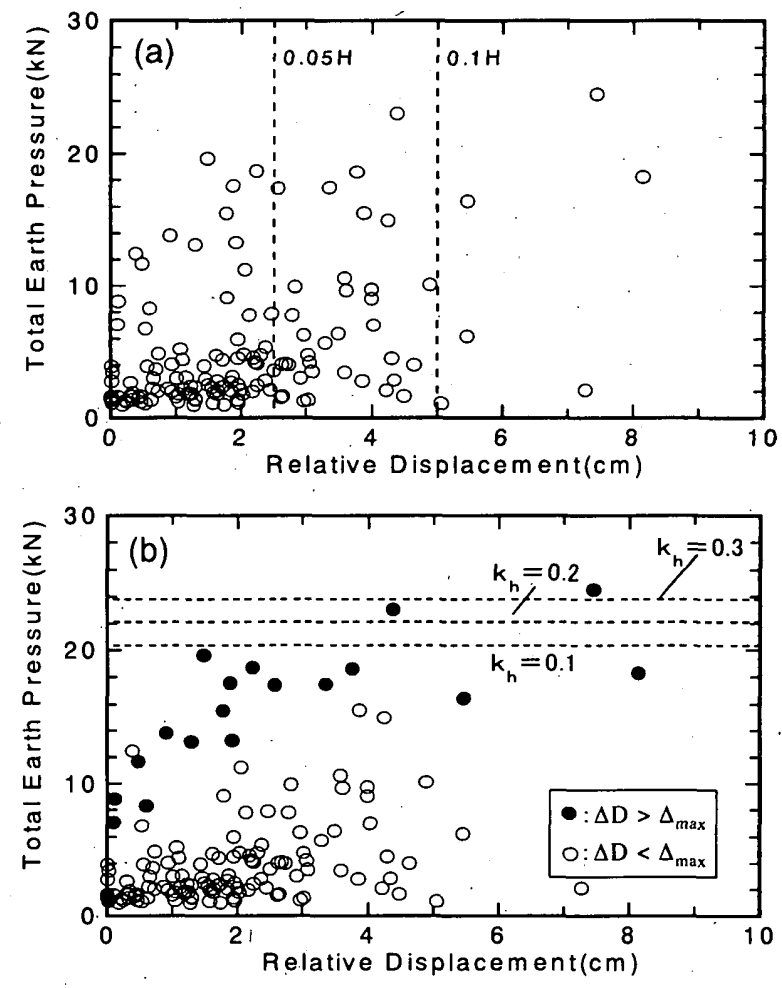

図ー5 相対変位と土圧合力ピーク. 

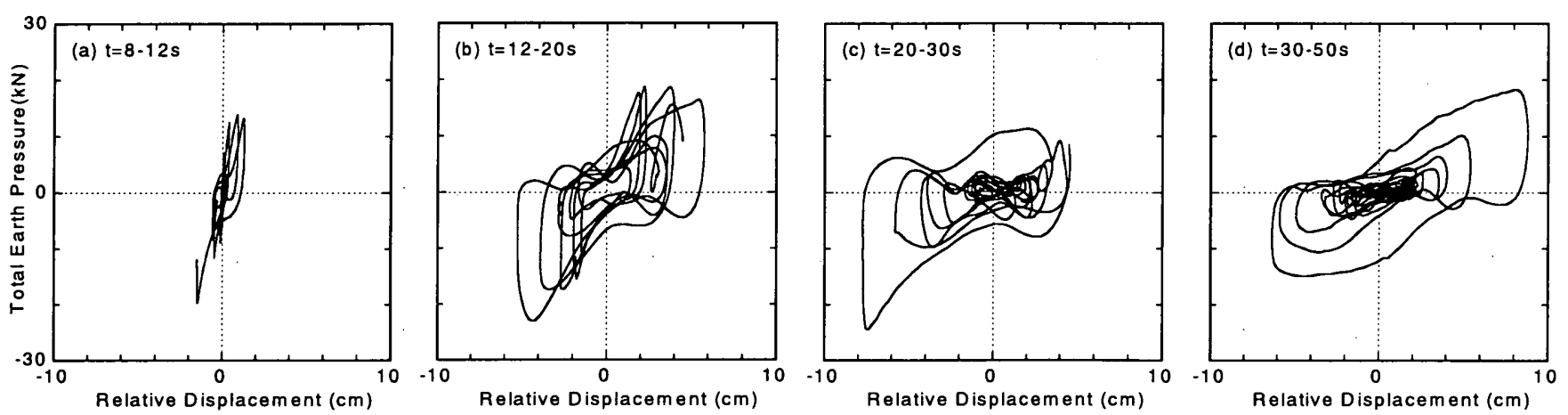

図 -6 基礎部と表層地盤の相対変位と土圧合力の関係

推定した水平震度 $\mathrm{k}_{\mathrm{h}}=0.1 、 0.2 、 0.3$ における受働状態の土王合力を破 線で示す。相対変位が過去に生じた相対変位の最大值を上まわり、か つ相対変位が $2 \mathrm{~cm}$ 程度（壁面高さの $4 \%$ ）以上になると、土圧は受働 状態に概ね達することが分かる。

\section{2 土圧が増加しはじめる限界相対变位}

土圧合力の発生メカニズムを検討するため、図ー 6に8〜12秒、12 〜20秒、20〜30秒および30〜50秒における相対変位と土圧合力の関 係を示す。8〜12秒では、相対変位が生じると土圧合力は直ちに增加 する。一方、12 20秒では、土圧合力はある相対変位までほとんど増 加せず、それを超えると急增する。時間が経つにしたがい、この傾向 が顕著になることを考慮すると、繰り返しの地盤変形のため基礎部 周辺の地盤が緩み、相対変位に起因する土圧変動が生じにくくなつ たと考えられる。以後、相対変位による土圧変動が生じにくい領域 を、「緩み領域」と呼ぶこととする。なお、相対変位が増加から減少 に転じると、土圧合力は急减して、相対変位によらず極めて小さい值 となる。このため、同じ相対変位でも、その増加過程と隇少過程で土 圧合力が大きく異なる。

図ー7に、緩み領域が生じた後の相対変位と土圧合力の関係を模 式図で示す。ここで、相対変位ゼロにおける土压合力を $\mathrm{P}_{\mathrm{E}}(0)$ とし、土 圧合力が $\mathrm{P}_{\mathrm{E}}(0)$ の $\alpha$ 倍になった時点の相対変位を $\Delta \mathrm{D}_{0}$ とする。図一 8 に $\alpha=1.1 、 1.2 、 1.3$ における $\Delta \mathrm{D}_{0}$ の時刻変化を示す。なお、 $\Delta \mathrm{D}_{0}$ は相対変 位ゼロにおける土圧合力が $1 \mathrm{kN}$ 以上のものを対象にした。10秒以降、 $\alpha$ によらず $\Delta D_{0}$ は增加し、土圧合力を発生させる相対変位が大きくな る。ただし、 $\alpha=1.1$ における $\Delta \mathrm{D}_{0}$ と $\alpha=1.2 、 1.3$ における $\Delta \mathrm{D}_{0}$ との差は 比較的小さい。このことは、 $\alpha=1.1$ に対応する $\Delta \mathrm{D}_{0}$ まで土圧合力の增 加が極めて小さく、その後、土圧合力は急増することを示唆してい る。したがって、 $\alpha=1.1$ における $\Delta \mathrm{D}_{0}$ を緩み領域に相当する限界相対

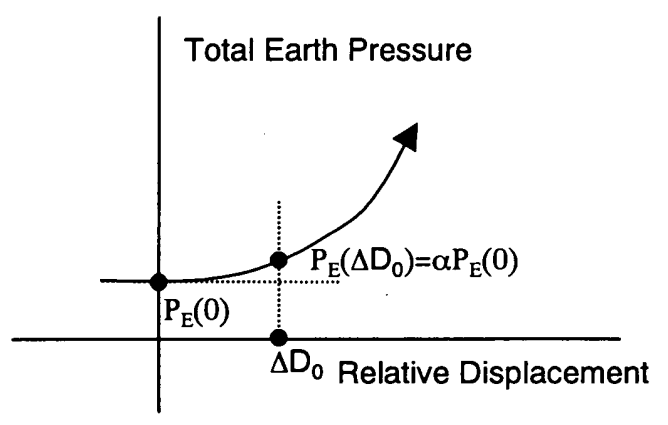

図-7 緩み領域（模式図）
変位とする。限界相対変位は加振開始から 10 秒付近まで0. $1 \mathrm{~cm}$ 以下と 極めて小さいが、その後、徐々に大きくなり、20秒以降では $1.5 \mathrm{~cm}$ 超える場合もある。時間が経つにしたがって限界相対変位が大きく なることから、過去の履歴が緩み領域に影響を与えていると考えら れる。

緩み領域をさらに検討するため、過去に生じた相対変位の最大值 で限界相対変位を除したものを図ー9に示す。無次元化した限界相 対変位は、時間によらず概ね0〜0.3の値となる。このことは、過去に 生じた相対変位の最大值を考慮することで、緩み領域をある程度の 精度で評価できることを示唆している。

\section{5 䌒み領域を考慮した地震時土圧理論}

5.1 䌅み領域を考慮した土圧合力の評価

前章の検討から、張らの理論に基づく手法では、受働状態に達する

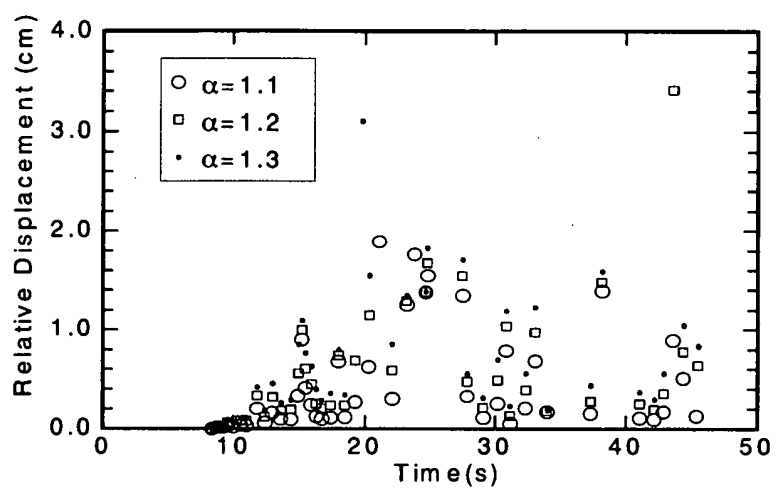

図 -8 土圧合力が増加しはじめる相対変位の時間変化

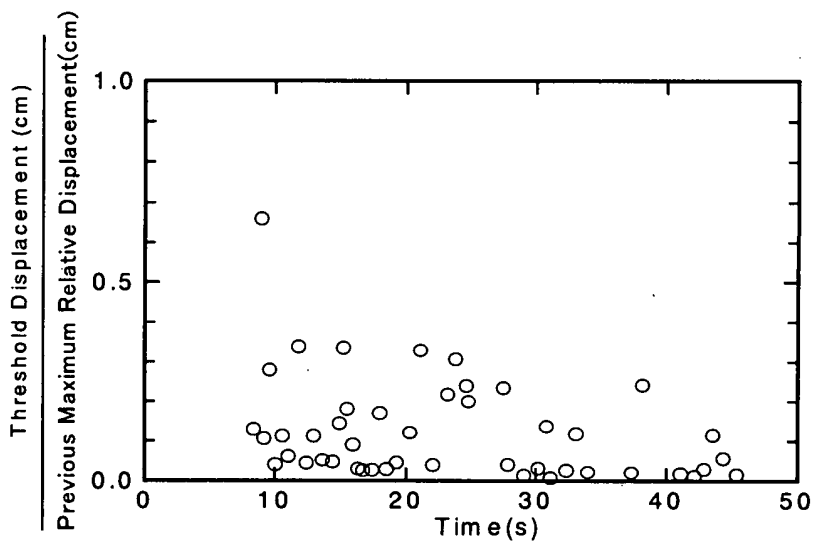

図-9 無次元化した限界相対変位の時間変化 
表 -3 側方ひずみ拘束係数（提案手法）

\begin{tabular}{|c|c|c|c|c|c|}
\hline & \multicolumn{2}{|c|}{ Active Side } & \multicolumn{3}{c|}{ Passive Side } \\
\hline$\Delta \mathrm{D}$ & \multicolumn{2}{|c|}{$\Delta_{\mathrm{a}}$} & 0 & \multicolumn{3}{c|}{$\Delta_{0}$} & $\Delta_{\mathrm{p}}$ \\
\hline $\mathrm{R}^{\prime}$ & -1 & $-\left(\Delta \mathrm{D} / \Delta_{\mathrm{a}}\right)^{0.5}$ & 0 & $\frac{3\left(\Delta \mathrm{D}-\Delta_{0}\right)^{0.5}}{\left(\Delta_{\mathrm{p}}-\Delta_{0}\right)^{0.5}}$ & 3 \\
\hline
\end{tabular}
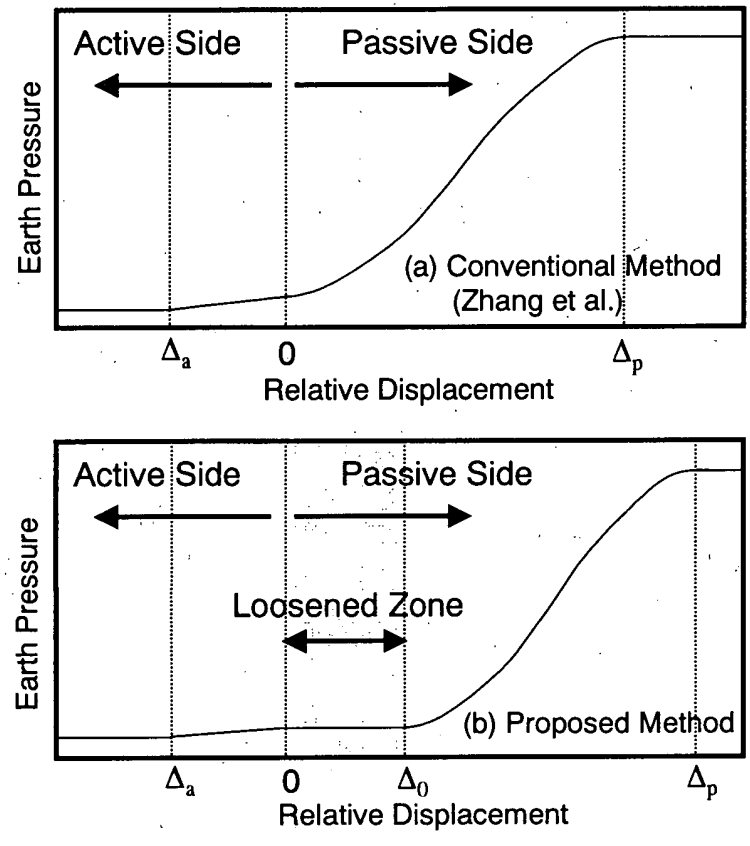

図-10 相対変位と土圧（模式図）

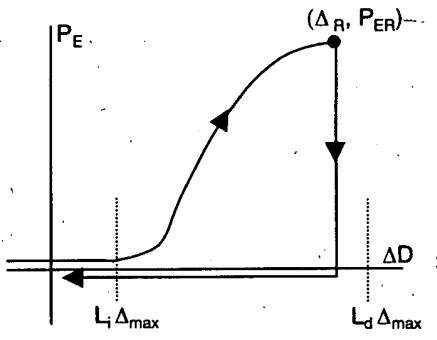

(a) $\Delta_{\mathrm{R}}<\mathrm{L}_{\mathrm{v}} \Delta_{\max }$

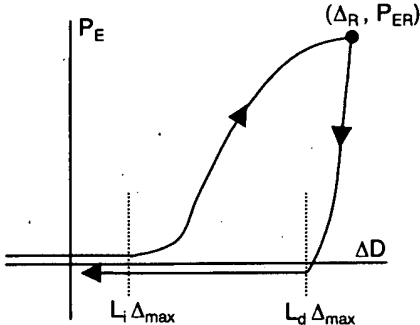

(b) $\Delta_{\mathrm{R}}>\mathrm{L}_{\mathrm{d}} \Delta_{\max }$
図-11 復元力特性（模式図）

相対変位が壁面高さのみに依存すると仮定し、液状化に伴う緩み領 域を考慮しなかったため、液状化後の土圧を過大に評価したと考え られる。また、緩み領域では相対変位に起因する土圧合力が発生しに くくなる。そこで、まず受働土圧に達する相対変位を、次式のように 仮定する。

$$
\Delta_{p}=\max \left(4.0 \times 10^{-2} H, \Delta_{\max }\right)
$$

ここに、 $\Delta_{\max }$ は過去に生じた地盤と基礎部の相対変位の最大值であ る。次に緩み領域を考慮した側方ひずみ拘束係数R' を表一 3 のよう に与える。表中の $\Delta_{0}$ は限界相対変位である。緩み領域では、相対変位 による土圧変動は発生しないと仮定し、側方ひずみ拘束係数をゼロ とする。そのため、地盤の加速度による物体力を無視すれば、受働側 の土圧は静止土圧と等しくなる。限界相対変位は、過去に生じた相対

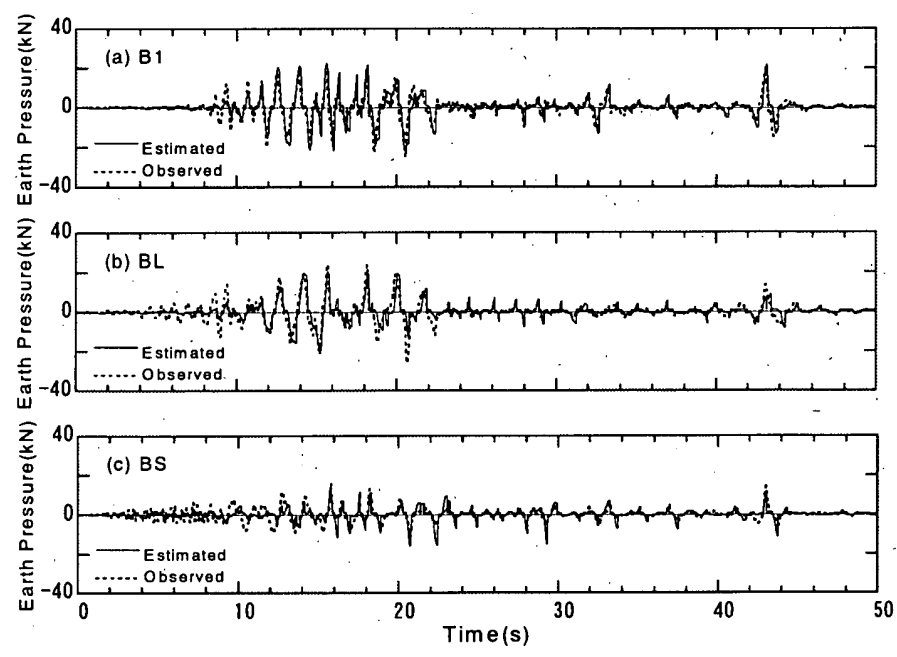

図ー 1-2 土圧合力の実験值と提案手法による推定值

変位の最大值に依存すると考え、次式で与えられるものとした。

$$
\begin{array}{ll}
\Delta_{0}=\mathrm{L}_{\mathrm{i}} \times \Delta_{\max } & \text { （相対変位の增加過程） } \\
\Delta_{0}=\mathrm{L}_{\mathrm{d}} \times \Delta_{\max } & \text { (相対変位の減少過程) }
\end{array}
$$

ここに、 $L_{i}$ は図-9から0〜0.3程度、 $L_{d}$ は相対変位の減少過程で土圧 合力がつねに極めて小さいことから、0.8程度の值をとるものと考え られる。以上から、受働土圧に達する相対変位を算定する(1.1) 式の代 わりに (13) 式、側方ひずみ拘束係数 $\mathrm{R}$ (表 -2 )の代わりに側方ひずみ 拘束係数R'（表－3）および(14)、（15）式を用いることで、緩み領域 を考慮した土圧合力の推定が可能になる。

図ー10は、張らの理論に基づく手法および提案手法における相対 変位と土圧の関係の模式図である。張らの理論に基づく手法の場合、 相対変位が生じると受働側で土圧が急增する。一方、提案手法の場 合、相対変位が限界相対変位より小さいと、受働側土圧は相対変位に よって変動しない。相対変位が限界相対変位より大きくなると、受働 側土圧は急增する。限界相対変位は、(14)、（15）式のように、過去に 生じた相対変位の最大值に比例して大きくなる。

復元力特性は、相対変位の増加過程と減少過程で限界相対変位が 異なるため、図ー11の模式図のようになる。図中の $\Delta_{\mathrm{R}}$ および $\mathrm{P}_{\mathrm{ER}}$ は、折

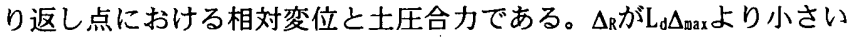
場合、折り返し点をすぎると、土圧合力は直ちにゼロに近い值になる （図一11a）。一方、 $\Delta_{R}$ が $\mathrm{L}_{d} \Delta_{\max }$ より大きい場合、折り返し点をすぎる と、土圧合力は相対変位とともに減少し、限界相対変位でゼロに近い 值になる（図-11b）。

\section{2 提案手法の妥当性の検討}

提案手法の妥当性を検討するため、BI、BL、BS、各乇デルの $240 \mathrm{~cm} / \mathrm{s}^{2}$ 加振 ${ }^{18)}$ に対し、提案手法で土圧合力を推定した。基礎部変 位、地盤変位、砂の単位体積重量、砂の内部摩摖角等の土圧算定条 件は、3.2節と同じとした。なお、（14）式のL 0.8 とした。図ー12に提案手法で推定した土圧合力の時刻歴を、実 験值とともに示す。推定值は、間隙水圧の発生がなく相対変位が極 めて小さい 8 秒以前では、実験值に比べやや小さいが、間隙水圧上 昇過程 (8〜24秒)、液状化後 (24秒以降) では、全モデで実験值と 概ね対応している。特に提案手法による推定值は、図ー4では対応 

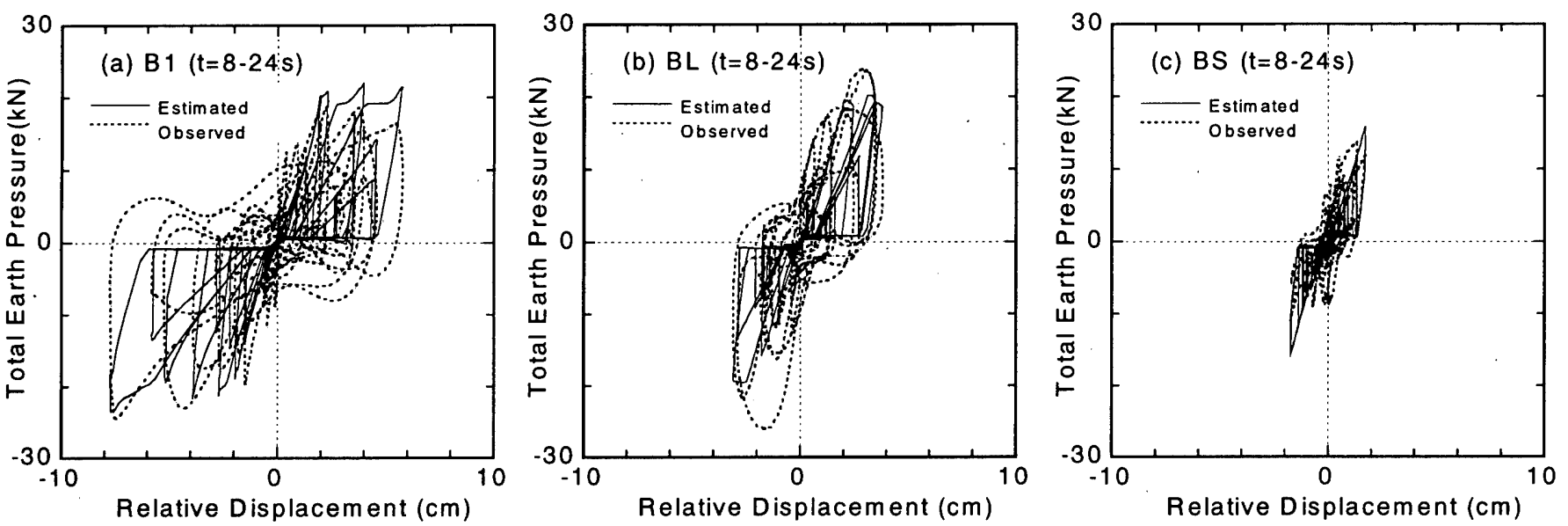

図-13 相対変位と土圧合力の関係（実験值と提案手法による推定值）

の悪かった液状化後における実験值との対応が良い。このことは、 受働状態に達する相対変位および緩み領域が適切に評価されている ことを示唆している。

提案手法の妥当性をさらに検討するために、図ー13に相対変位と 土圧合力の関係を、土圧合力が最も大きい8～24秒について、提案 手法による推定值と実験值を比較して示す。実験值の場合、B1の相 対変位・土圧合力が最も大きく、BSの相対変位・土圧合力が最も小 さい。BLは、BSとB1の中間に位置する。提案手法による推定值は、 各モテルの特徴をとらえ、土圧合力のピーク值のみならず復元力特 性も実験值と概ね対応する。以上から、間隙水圧上昇過程および液 状化後における土圧合力を、提案手法で簡便に推定できると考えら れる。

\section{6. まとめ}

大型せん断土槽を用いた液状化実験に基づき、液状化層の上に存 在する表層の非液状化層が基礎根入れ部に及ほす土圧合力の評価法 を検討し、以下の結果を得た。

（1）液状化が進行すると、繰り返しの地盤変形のため基礎部周辺の地 盤が緩み、相対変位に起因する土圧変動が発生しにくい「緩み領域」 が生じる。緩み領域は、過去に生じた相対変位の最大值を考慮するこ とで、概ね評価することができる。

（2）受働状態に達する基礎部と地盤の相対変位を評価するためには、 壁面高さのみならず、過去に生じた相対変位の最大值を考慮する必 要がある。

（3）楥み領域を考慮し、張らの地震時土圧理論を発展させることで、 間隙水圧上昇過程および液状化後における土圧合力を、ある程度の 精度で簡便に推定することが可能である。

\section{謝辞}

本実験は防災科学技術研究所、東京工業大学、鹿島建設、大成建設、竹中工 務店、新日本製鐵、東京侧サーチの共同で行ったものである。関係者に記して感 謝いたします。

\section{参考文献}

1）日本建策学会，阪神・淡路大震災調查報告，建筑編 -4 ，木質菁造・建築基 碳櫣造, 1998.

2) Tokimatsu, K. and Asaka, Y. : Effects of Liquefaction-induced Ground Displacements on Pile Performance in the 1995 Hyogoken-Nambu Earthquake, Soils and Foundations, Special Issue on Geotechnical Aspects of the 1995 Hyogoken Nambu
Earthquake, No. 2, pp. 163-177, 1998.9

3) Miyamoto, Y., Miura, K., Scott, R.F. and Hushmand, B.: Pile Foundation Response in Liquefiable Soil Deposit during Strong Earthquakes, 日本建築学会構造系諭文 報告集, 第439号, pp.49-63, 1992.9

4）水野二十一，杉本三千椎, 飯場正紀, 森利弘, 平出努:液状化過程における杭 基礎の動的挙動, 第10回日本地震工学シンポジウム詥文集, Vol.2, pp.1635$1640,1998.11$

5) Horikoshi, K., Tateishi, A. and Fujiwara, T.: Centrifuge Modeling of a Single Pile Subjected to Liquefaction-induced Lateral Spreading, Soils and Foundations, Special Issue on Geotechnical Aspects of the 1995 Hyogoken Nambu Earthquake, No. 2, pp. 193-208, 1998. 9

6）小林勝已，八幡夏恵子，難波伸介，仙頭紀明，小林恒一, 白演正芳, 林理 : ポートアイランド内陸部における建築基礎杭の被害の解析，第 5 回構造物 と地盤の動的相互作用シンポジウム, 日本建築学会, pp.187-192, 1998.5

7）建設省住宅局建築指導課 監修：地震力に対する建築物の基整の設計指針, 日本建築センター, 1984

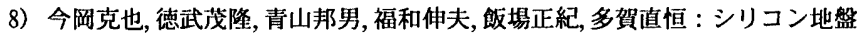
模型を用いた動的根入扎効果に関する研究, 第10回日本地震工学シンポジ ウム論文集, Vol.2, pp.1653-1658, 1998. 11

9）物部長穂: 地震上下動に関する考察ならびに振動雑諭, 土木学会誌, 10(5), pp.1063-1094, 1924

10) Okabe. S.: General Theory on Earth Pressure and Seismic Stability of Retaining Wall and Dam, 土木学会訫, 10(6), pp. 1277-1323, 1924

11) 張建民, 社本康広, 時松孝次: 構造物の地下壁に加わる地震時土圧の評価法, 第 5 回構造物と地盤の動的相互作用シンポジウム, 日本建築学会, pp.231236, 1998. 5

12) Zhang, J. -M., Shamoto, Y. and Tokimatsu K. : Seismic Earth Pressure Theory for Retaining Walls under Any Lateral Displacement, Soils and Foundations, Vol. 38, No. 2, pp. 143-163, 1998. 7

13）内山正次, 山下利夫: 深く埋込まれた構造物の地震時侧面土圧の挙動に関す る実験的研究, 日本建築学会構造系諭文集, 第516号, pp.105-112, 1999.2

14）井口道雄, 武藤尊彦, 筫輪親宏 : 大型振動台基礎侧面に作用する地震時土圧 の钼測と解析, 日本建築学会檴造系論文集, 第561号, pp.65-72, 2002.11

15) Sherif, M. and Fang, Y. S.: Dynamic Earth Pressures on Walls Rotaing about the Top, Soils and Foundations, Vol. 24, No. 4, pp. 108-117,1984.12

16) Ishibashi, I. and Fang, Y. S.: Dynamic Earth Pressures with Different Wall Movement Modes, Soils and Foundations, Vol. 27, No. 4, pp. 11-22, 1987. 12

17）風間基樹,稲富隆昌:ケーソンに作用する地震時土圧に関する模型振動実験, 土木学会論文集, No. 416/ I-13, pp.419-428, 1990.4

18）田村修次, 時松孝次, 宮崎政信, 八幡夏恵子, 土屋富男 : 大型せん断土槽を用 いた液状化実験における基礎根入れ部に加わる土圧, 日本建策学会構造系 論文集, No.554, pp.95-100, 2002. 4

19）田村修次、時松孝次、内田明彦、船原英樹、阿部秋男:大型せん断土槽を用 いた液状化実験における基礎根入れ部に加わる土生合力と構造物慣性力の 関係、日本建築学会橉造系論文集, No.559,pp.129-134, 2002.9

20）財団法人日本建築防災協会臨海部構造安全委員会：「臨海部における大規 模建築物群の総合的な構造安全に関する調查・検討報告書」総集編, pp.8$11,1992.3$ 